\title{
Making Urban Agriculture an Intentional, Equitable City Redevelopment Strategy
}

\author{
Christina D. Rosan* \\ Geography and Urban Studies, Temple University, Philadelphia, PA, United States
}

Keywords: urban agriculture, vacant land, "green gentrification", "growth machine", redevelopment

\section{INTRODUCTION}

Urban agriculture is exciting. Growing food on formerly vacant lots in U.S. cities brings with it the promise of solving multiple problems at once by addressing concerns about community engagement, vacant land reuse, climate resiliency, heat island effects, property values, food justice, food security, mental and physical health, green infrastructure, environmental education, and empowerment of low-income communities, etc. (Wekerle, 2004; Heckert and Mennis, 2012; Carlet et al., 2017; Horst et al., 2017; Rosan and Pearsall, 2017). While these benefits are numerous and exciting, in the U.S. increasingly scholars and policy-makers need to focus on the complicated and contradictory role that urban agriculture plays in urban redevelopment processes. Urban agriculture fits into a larger, tension-ridden, narrative of inequitable urban redevelopment that highlights the fraught history of American cities marked by suburbanization,

OPEN ACCESS

Edited by:

Helda Morales,

The South Border College

(ECOSUR), Mexico

Reviewed by:

Laura Saldivar,

Independent Researcher,

Mexico City, Mexico

*Correspondence:

Christina D. Rosan

cdrosan@temple.edu

Specialty section:

This article was submitted to Agroecology and Ecosystem Services,

a section of the journal

Frontiers in Sustainable Food Systems

Received: 24 January 2020

Accepted: 28 April 2020

Published: 26 June 2020

Citation:

Rosan CD (2020) Making Urban Agriculture an Intentional, Equitable

City Redevelopment Strategy.

Front. Sustain. Food Syst. 4:74.

doi: 10.3389/fsufs.2020.00074 redlining, disinvestment, neoliberal policies, structural racism, lack of access to capital, toxic legacies, environmental injustice, power imbalances, and now a return to cities marked by a push for sustainable planning and very real concerns about gentrification, "green gentrification," and displacement of people of color (Rosan and Pearsall, 2017; Rothstein, 2017; Anguelovski et al., 2018; McClintock et al., 2018b).

\section{FROM "CIVIC ECOLOGY” TO “GREEN GENTRIFICATION"}

Urban agriculture is a "shape shifter" and in some ways a victim of the "success" of gentrifying cities: the scholarly understanding of urban agriculture has quickly shifted from being about community led self-sufficiency and resilience, what Krasny and Tidball (2012) refer to as "civic ecology" to being more nefariously associated with "environmental gentrification" (Dooling, 2009) "green gentrification" (Pearsall, 2010; Anguelovski et al., 2019), "ecogentrification” (McClintock et al., 2018a), and "green aesthetics" (Aptekar and Myers, 2020).

Urban agriculture highlights the tensions associated with the "growth machine" paradigm of urban planning that Logan and Molotch (1987) describe where land is valued for its exchange over use value and cities seek to maximize the exchange value of land and subsequent associated tax revenue. Recognizing the economic "drain" that vacant land has on cities, urban agriculture has been historically discussed as a means of stabilizing neighborhoods and capitalizing on disinvestment by putting the land to "good use" (Carlet et al., 2017). However, in many U.S. cities, urban agriculture is a strange animal in the urban "growth machine" story because historically the need and possibility of urban agriculture comes about due to structural racism and the systematic devaluation of urban land. We need to acknowledge that the vacant land in American cities is a result of systematic racism and we need to actively work to make sure that "our solutions" to urban vacancy do not repeat history. Today, the effectiveness of urban agriculture at addressing community concerns and its ability to address racism and actively meet equity goals are limited by 
the "revaloration" of urban land through gentrification (Ernwein, 2017; Rosan and Pearsall, 2017; Anguelovski et al., 2018).

Relying on urban agriculture to "fix" neighborhoods obscures the historical questions about neighborhood decline and disinvestment: Why is land vacant in black and brown communities in the first place? Who was disenfranchised? What role did redlining play in racialized access to homeownership and access to capital? There are also important questions that need to be asked about who will benefit from "fixing" neighborhoods. Is the hope that the neighborhood becomes "stabilized"? If so, for whom and by whom? Are policy-makers supporting urban agriculture anticipating that a new group of people will come to the city who will help raise property taxes or do we have mechanisms to protect low-income peoples' right to live in their neighborhoods and shape their futures, particularly when they have contributed their unpaid labor to urban agricultural and other "stabilization" initiatives? To what extent is equity and social justice a goal of urban agriculture planning, if there is planning at all? When we are thinking about redeveloping and reusing vacant urban space, is this when we should be asking questions about community control, and turning to more "radical" solutions like cooperative land ownership models and community land trusts? In what ways can we promote economic and racial justice with community planning for urban agriculture and other uses? Who gets to decide about the reuse of vacant land in cities and what communities need? Do we have mechanisms such as affordable housing, rent restrictions, and income based property taxes to protect residents from associated rising rents and property values?

Perhaps it is no surprise that conversations about urban agriculture find themselves mired in debates about urban land development and the "right to the city" since urban agriculture is inextricably linked to the value of urban land and the value of land is a reflection of larger historical, structural changes in cities and regions (Harvey, 2003; McClintock, 2014; Tornaghi, 2014; Kumnig, 2017). With a growing "return" by higher income (and often white residents) and an interest in urban and more "sustainable" living, U.S. cities are seeing rapid redevelopment and reuse of vacant land (Anguelovski, 2015). As once vacant and undervalued land becomes more valuable, we see increases in property values, taxes, rents, and the resulting gentrification and displacement of low-income residents. "Improvements" in the urban environments associated with the shifting demographics painfully highlight the historical and current inequities in the way that communities of color have been treated by both scholars and city officials. While low-income and minority communities have lived for decades in neighborhoods with high rates of crime, disinvestment, environmental injustice, and a lack of urban environmental, social, and economic amenities, when the demographics change to include wealthier residents, we see a reorienting of the relationship between these neighborhoods and the rest of the city (Heckert and Rosan, 2016). Higher income residents demand the same access to services in these neighborhoods that have been a "given" in higher income urban neighborhoods and American suburbs. They have the political capital and capacity to be heard; the fact that the urban land now brings in higher property taxes is used as an excuse by city officials to finally pay attention to these demands and take action, notwithstanding the fact that they systematically ignored community concerns in these same neighborhoods for years. At the same time, the very important community building work that has been done by low-income, minority residents, is at risk as these same communities find themselves at risk of displacement (Wekerle, 2004; Tornaghi, 2014; Anguelovski, 2015; Anguelovski et al., 2018). In effect, we see an erasure of the important and often traumatic history of urban communities of color and the important leadership role they played in community stabilization in the face of systematic racism and disinvestment. In the new condo developments with green amenities and urban gardens, we often only see a palimpsest of a racist American historical urban experience that systematically excluded many low-income, primarily African American communities for generations.

As the neighborhood demographics change in U.S. cities, so too does the conversation about urban agriculture and its role in the urban environment. The new, more privileged and politically powerful (and increasingly white) residents of the city want to be able to enjoy gardening and growing their own food in a community garden (Anguelovski, 2015). They also want environmental justice concerns addressed. Urban agriculture in these "revalorized" neighborhoods is seen as an urban amenity, but the wealthier residents are not satisfied with the notion that this is where they should get their food from. Here is where we expose the neoliberal bias of some of the past writings about urban agriculture (McClintock, 2014). Whereas urban agriculture was seen as a way to address "food deserts" and a lack of access to services and amenities in low-income communities, as the neighborhood gentrifies, grocery stores arrive, vacant lots are cleaned up, and trash removal is expected (Meenar and Hoover, 2012). Scholars today are rarely writing stories of how wealthy residents in gentrifying neighborhoods are empowered through urban agriculture and "community" is created in urban gardens. City officials and non-profits are not lauding the notion that higher income residents are growing their own food to survive. Instead of questioning the neoliberal narrative that communities need to essentially "fix themselves" when they have been systematically discriminated against (McClintock, 2014), many scholars have shifted their attention to neoliberal critiques of "green gentrification" (Gould and Lewis, 2016).

\section{COORDINATED PLANNING TO BUILD EQUITABLE COMMUNITIES, NOT "FIXING" PLACE}

The notion that greening and gentrification are related should not be a surprise to scholars who have been writing for years about the "benefits" of greening and urban agriculture to urban communities. Did we not anticipate that as neighborhoods improved, they would be revalorized? However, policy-makers and scholars alike have been surprised by the speed at which "green gentrification" has contributed to a remaking of the urban landscape. Unfortunately, the "green gentrification" literature has surprisingly few answers to whether it is possible to improve neighborhoods and keep low-income and minority communities 
in place. Perhaps the strongest argument is the notion of "just green enough," an approach that argues that particular types of green space development may be able to improve neighborhoods without significantly driving gentrification and displacement (Wolch et al., 2014). I argue that this "just green enough" is not enough and that we need to rethink the way we plan our cities to deliberately and comprehensively address affordability and actively prevent displacement. We need a more "radical" narrative around urban agriculture and greening and redevelopment in U.S. cities that is guided by the need to develop policies that address racial discrimination, disenfranchisement, loss of community control, and displacement of low-income, often minority residents. If we want urban agriculture and urban greening to do everything we hope it will (and not promote "green gentrification"), and the goal is to promote racial and socio-economic equity in cities, it needs to be viewed as a part of a much larger, much more intentional, and much more "radical" approach to creating equitable and sustainable cities. We need to acknowledge our troubled urban history: the deep systematic exclusion and racism that make urban agriculture both necessary and possible. We need more scholars and policy-makers to propose and implement innovative and radical ideas about how to use community land trusts, and cooperative ownership of land that provide alternatives to the "exchange over use value," "growth machine" paradigm. We also need collaborative urban governance where urban agriculture, urban greening, affordable housing, and other community infrastructure like schools, public transit, parks, hospitals, and grocery stores are planned for together. Together, these are the building blocks

\section{REFERENCES}

Anguelovski, I. (2015). Healthy food stores, greenlining and food gentrification: contesting new forms of privilege, displacement and locally unwanted land uses in racially mixed neighborhoods. Int. J. Urban Regional Res. 39, 1209-1230. doi: 10.1111/1468-2427.12299

Anguelovski, I., Connolly, J., and Brand, A. L. (2018). From landscapes of utopia to the margins of the green urban life. City 22, 417-436. doi: 10.1080/13604813.2018.1473126

Anguelovski, I., Connolly, J. J., Garcia-Lamarca, M., Cole, H., and Pearsall, H. (2019). New scholarly pathways on green gentrification: what does the urban 'green turn'mean and where is it going?. Progress Human Geogr. 43, 1064-1086. doi: $10.1177 / 0309132518803799$

Aptekar, S., and Myers, J. S. (2020). The tale of two community gardens: green aesthetics versus food justice in the big apple. Agric. Hum. Values (2020). doi: 10.1007/s10460-019-10011-w

Carlet, F., Schilling, J., and Heckert, M. (2017). Greening US legacy cities: urban agriculture as a strategy for reclaiming vacant land. Agroecol. Sustain. Food Syst. 41, 887-906. doi: 10.1080/21683565.2017.13 11288

Dooling, S. (2009). Ecological gentrification: a research agenda exploring justice in the city. Int. J. Urban Regional Res. 33, 621-639. doi: 10.1111/j.1468-2427.2009.00860.x

Ernwein, M. (2017). Urban agriculture and the neoliberalisation of what? ACME Int. J. Crit. Geogr. 16, 249-275.

Gould, K. A., and Lewis, T. L. (2016). Green Gentrification: Urban Sustainability and the Struggle for Environmental Justice. London: Routledge.

Harvey, D. (2003). The right to the city. Int. J. Urban Regional Res. 27, 939-941. doi: $10.1111 / j .0309-1317.2003 .00492 . x$ of sustainable, equitable, and resilient communities, which will be critical as we face the climate challenges ahead. They are the types of community amenities that higher-income residents expect as a matter of course and lower-income residents deserve. This requires working with policy-makers to rethink traditional siloed urban governance strategies that focus on "fixing" places through greening and growing and fail to build in safeguards to protect residents' right to live in thriving urban communities. We owe it to the residents of these communities, who have been victims of historical, systematic discrimination and disenfranchisement, to work collaboratively with them to make sure they define what "fixing" the neighborhood entails and ensure that long-term residents of all income groups can stay in their neighborhoods once they are "fixed." This will require new approaches to planning guided by achieving equity as an outcome. If we fail, urban agriculture will not be the great exciting experiment that we hoped it would be. Instead, it will a part of a story of "green gentrification." It will be a palimpsest: a photo of an urban farm located in the condo gym that replaced it.

\section{AUTHOR CONTRIBUTIONS}

The author confirms being the sole contributor of this work and has approved it for publication.

\section{ACKNOWLEDGMENTS}

Thank you to the external reviewer for your helpful comments.

Heckert, M., and Mennis, J. (2012). The economic impact of greening urban vacant land: a spatial difference-in-differences analysis. Environ. Plann. A 44, 3010-3027. doi: 10.1068/a4595

Heckert, M., and Rosan, C. D. (2016). Developing a green infrastructure equity index to promote equity planning. Urban Forest. Urban Green. 19, 263-270. doi: 10.1016/j.ufug.2015.12.011

Horst, M., McClintock, N., and Hoey, L. (2017). The intersection of planning, urban agriculture, and food justice: a review of the literature. J. Am. Plann. Assoc. 83, 277-295. doi: 10.1080/01944363.2017.1322914

Krasny, M. E., and Tidball, K. G. (2012). Civic ecology: a pathway for Earth Stewardship in cities. Front. Ecol. Environ. 10, 267-273. doi: 10.1890/1 10230

Kumnig, S. (2017). Between green image production, participatory politics and growth: urban agriculture and gardens in the context of neoliberal urban development in vienna. ACME Int. J. Crit. Geogr. 16, 232-248. Available online at: https://acme-journal.org/index.php/acme/article/view/1393

Logan, J. R., and Molotch, H. L. (1987). Urban Fortunes: The Political Economy of Place. Berkeley, CA: University of California Press.

McClintock, N. (2014). Radical, reformist, and garden-variety neoliberal: coming to terms with urban agriculture's contradictions. Local Environ. 19, 147-171. doi: 10.1080/13549839.2012.752797

McClintock, N. (2018a). Cultivating (a) sustainability capital: urban agriculture, ecogentrification, and the uneven valorization of social reproduction. Ann. Am. Assoc. Geogr. 108, 579-590. doi: 10.1080/24694452.2017.13 65582

McClintock, N., Miewald, C., and McCann, E. (2018b). "The politics of urban agriculture: sustainability, governance, and contestation," in The Routledge Handbook on Spaces of Urban Politics, eds K. Ward, A. E. Jonas, B. Miller, and D. Wilson (Routledge; Thousand Oaks, CA: SAGE), 361-374. 
Meenar, M. R., and Hoover, B. M. (2012). Community food security via urban agriculture: understanding people, place, economy, and accessibility from a food justice perspective. J. Agric. Food Syst. Commun. Dev. 3, 143-160. doi: 10.5304/jafscd.2012.031.013

Pearsall, H. (2010). From brown to green? Assessing social vulnerability to environmental gentrification in New York City. Environ. Plann. C Govern. Policy 28, 872-886. doi: 10.1068/c08126

Rosan, C. D., and Pearsall, H. (2017). Growing a Sustainable City?: The Question of Urban Agriculture. Toronto: University of Toronto Press.

Rothstein, R. (2017). The Color of Law: A Forgotten History of How Our Government Segregated America (New York, NY: Liveright), 345.

Tornaghi, C. (2014). Critical geography of urban agriculture. Progress Human Geogr. 38, 551-567. doi: 10.1177/0309132513512542

Wekerle, G. R. (2004). Food justice movements: policy, planning, and networks. J. Plann. Educ. Res. 23, 378-386. doi: 10.1177/0739456X04264886
Wolch, J. R., Byrne, J., and Newell, J. P. (2014). Urban green space, public health, and environmental justice: the challenge of making cities 'just green enough'. Landsc. Urban Plann. 125, 234-244. doi: 10.1016/j.landurbplan.2014.01.017

Conflict of Interest: The author declares that the research was conducted in the absence of any commercial or financial relationships that could be construed as a potential conflict of interest.

Copyright (c) 2020 Rosan. This is an open-access article distributed under the terms of the Creative Commons Attribution License (CC BY). The use, distribution or reproduction in other forums is permitted, provided the original author(s) and the copyright owner(s) are credited and that the original publication in this journal is cited, in accordance with accepted academic practice. No use, distribution or reproduction is permitted which does not comply with these terms. 